Article history: Submitted 2 August 2020; Accepted 16 September 2020; Available online 1 October 2020.

\title{
Pertanggungjawaban Pidana Pengguna Jasa Prostitusi Online
}

\author{
Winda Hayu Rahmawati \\ windahayur@gmail.com \\ Universitas Airlangga
}

\begin{abstract}
Keywords:
Prostitution;

Service users;

Criminal liability.

Abstract

In Indonesia, prostitution is a criminal offense which has been practiced throughout ancient and modern time. Especially with the expansion of sophisticated information and communication technology such as social media, prostitution activities are facilely to do. At this juncture, there are still no detailed regulations governing a ban on prostitution. Prostitution activities are only regulated in the Penal Code KUHP which can only be imposed on pimps only. Other parties such as service providers and service users, who are also involved in carrying out prostitution activities, cannot be ensnared since there is still no regulation about the prostitution activity. To answer the problem formulation, a research with statue approach and conceptual approach was conducted. Referring to the results of the research conducted, based on Indonesian national law, service users of online prostitution service still cannot be criminally accounted due to the fact that there are still no regulation which can ensnare them. The service users of online prostitution service can only be accounted through Article 55 KUHP and the Local Government Regulation in each region which have regulated prostitution activities. For this reason, it is necessary to reform the criminal law policies so that the prevention of prostitution can be maximized.
\end{abstract}

\begin{abstract}
Kata Kunci:
Abstrak

Prostitusi;

Di Indonesia, kegiatan prostitusi merupakan suatu tindak pidana yang telah Pengguna jasa; ada dari jaman dahulu hingga sekarang. Apalagi dengan adanya perkembangan Pertanggungjawa- teknologi informasi dan komunikasi seperti media sosial, kegiatan prostitusi ban Pidana. mengatur secara rinci perihal larangan kegiatan prostitusi. Kegiatan prostitusi hanya diatur dalam KUHP yang hanya dapat dikenakan pada mucikari saja. Sedangkan pihak lain seperti penyedia jasa dan pengguna jasa yang juga turut terlibat dalam melaksanakan kegiatan prostitusi masih belum ada pengaturan yang dapat menjerat keduanya. Untuk menjawab rumusan masalah tersebut, dilakukan penelitian dengan pendekatan perundang-undangan dan pendekatan konseptual. Merujuk pada hasil dari penilitian yang dilakukan, berdasarkan hukum nasional Indonesia, pengguna jasa prostitusi online masih belum dapat dipertanggungjawabkan secara pidana sebab masih belum ada aturan yang dapat menjerat para pengguna jasa prostitusi. Pengguna jasa prostitusi online hanya dapat dipertanggungjawabkan melalui Pasal 55 tentang penyertaan dan melalui Peraturan Daerah di masing-masing daerah yang telah mengatur tentang kegiatan prostitusi. Sebab itu perlu adanya pembaharuan kebijakan hukum pidana agar penanggulangan terhadap kegiatan prostitusi online dapat lebih maksimal.
\end{abstract}




\section{Pendahuluan}

Seiring dengan pesatnya perkembangan teknologi, kini segala kebutuhan manusia menjadi lebih mudah untuk dilaksanakan. Hal ini sejalan dengan bunyi Pasal 28F Undang-Undang Dasar Negara Republik Indonesia Tahun 1945 yang menegaskan bahwa setiap warga negara berhak untuk berkomunikasi dan memperoleh informasi untuk mengembangkan pribadi dan lingkungan sosialnya, serta berhak untuk mencari, memperoleh, memiliki, menyimpan, mengolah, dan menyampaikan informasi dengan menggunakan segala jenis saluran yang tersedia. Namun hal tersebut tidak luput dari dampak-dampak positif dan negatif yang mana dapat merugikan manusia itu sendiri.

Dampak positif bisa kita nikmati dengan adanya kemudahan akses untuk mendapatkan informasi dan komunikasi, juga dengan adanya akses internet yang mana dapat menambah wawasan dan pengetahuan. Di saat yang sama, kita tidak bisa terhindar dari dampak negatif perkembangan teknologi. Berbagai muatanmuatan yang melanggar asusila seperti pornografi banyak tersebar di internet, maraknya kasus penipuan hingga tersebarnya informasi palsu (hoax) semakin banyak ditemui.

Kini kehidupan masyarakat dipengaruhi oleh perkembangan teknologi informasi dan komunikasi, tidak hanya memiliki sisi postitf sebagai alat untuk mempermudah kegiatan sehari-hari, namun juga memiliki sisi negatif termasuk di bidang kesusuilaan yang saat ini seringkali ditemui seperti prostitusi online, penggunaan internet untuk tujuan-tujuan seksual, atau menggunakan komputer untuk setiap bentuk ekspresi atau kepuasan seksual (cybersex). ${ }^{1}$ Dengan adanya akses internet dan mudahnya cara untuk berkomunikasi, transaksi dalam hal seks komersial juga semakin mudah untuk didapatkan.

Saat ini, penggunaan media sosial tidak hanya menjadi sarana untuk bersosialisasi atau bertukar informasi, namun juga sebagai alat untuk berinteraksi, menjadi jembatan yang praktis guna melakukan suatu bisnis, jasa, atau sumber

\footnotetext{
1 Barda Nawawi Arief, Pornografi, Pornoaksi dan Cybersex-Cyberporn (Pustaka Magister 2011).[78].
} 
sosialisasi dan digunakan sebagai media untuk melakukan kegiatan-kegiatan terlarang. Media sosial saat ini seringkali digunakan sebagai sarana yang mudah dan dianggap paling efisien untuk memenuhi target/sasaran dalam melakukan transaksi bisnis yang melibatkan prostitusi. Semakin meningkatnya kegiatan prostitusi melalui situs internet, semakin banyak pula terlihat para pekerja seks komersial yang menggunakan media sosial sebagai suatu cara untuk menjajakan dirinya dalam menarik para klien. ${ }^{2}$

Prostitusi merupakan suatu kegiatan yang tidak hanya melibatkan pelacurnya saja, namun konsep prostitusi lebih luas yang mana dalam kegiatan prostitusi juga banyak melibatkan pihak lain seperti germo, calo, serta konsumenkonsumen yang sebagian besar pelakunya merupakan laki-laki yang sering kali luput dari perhatian aparat penegak hukum. ${ }^{3}$ Di Indonesia, aturan-aturan yang berlaku tidak secara tegas melarang adanya praktek prostitusi. Tidak tegas dalam hal ini bahwa aturan-aturan di Indonesia tidak mengatur perihal sanksi bagi pengguna jasanya, sehingga mereka yang menggunakan jasa prostitusi sering kali lolos dari jeratan hukum sebab tidak bisa dipertanggungjawabkan, dan mereka yang menggunakan jasa pekerja seks komersial pun dapat dengan leluasa dapat meningkatkan praktik prostitusi tanpa takut terjerat sanksi hukum pidana. ${ }^{4}$

Di Indonesia, dalam kegiatan prostitusi yang dapat dikenakan pidana hanya mucikari saja, tetapi seiring berkembangnya kebijakan hukum pidana, penyedia jasa prostitusi dapat dipertanggungjawabkan menggunakan UU ITE ketika ia turut melakukan penawaran diri melalui media sosial dengan menguggah foto-foto yang bermuatan konten asusila. Sedangkan pria hidung belang yang memanfaatkan kegiatan prostitusi dengan cara membeli jasanya sering kali lolos dan tidak terjerat hukuman, sebab itulah para pria hidung belang masih

2 Suprojo, 'Penegakan Hukum Pidana dalam Penanggulangan Pekerja Seks Komersial (PSK) di Kabupaten Demak', Skripsi (Universitas Negeri Semarang 2016).[3].

3 Khorrul Imam Syafrudin Kalo, dkk, Pertanggungjawaban Pelaku Tinda Pidana Prostitusi Online Ditinjau dari Undang-Undang Nomor 11 Tahun 2008 Tentang Informasi dan Transaksi Elektronik (Studi Putusan Nomor 267/Pid.B/2015/PN. Pgp) (2018) 6 USU Law Journal.[96].

4 Subaidah Ratna Juita, dkk, ‘Reformulasi Pertanggungjawaban Pidana pada Pelaku Prostitusi Online: Suatu Kajian Normatif' (2016) 8 Jurnal Dinamika Sosial Budaya.[155]. 
suka memanfaatkan kegiatan prostitusi online untuk kesenangannya sendiri, karena mereka tak lagi takut dan merasa aman dan leluasa untuk menggunakan dan melakukan transaksi dalam hal seks komersial. Padahal kegiatan prostitusi merupakan suatu kegiatan tercela yang dapat merusak moral bangsa, dan harusnya tiap-tiap pihak yang turut melakukan kegiatan prostitusi patut dikenai pertanggungjawaban pidana. Tidak adanya pengaturan dan penegakan hukum yang lemah membuat penanggulangan terhadap tindak pidana prostitusi online jadi tidak maksimal.

\section{Aspek Hukum Pidana Prostitusi Online}

Merujuk pada hukum nasional yang berlaku, pada dasarnya melakukan hubungan seksual dengan seseorang atas dasar suka sama suka tidak dapat dipidana. Namun hal tersebut dikecualikan dalam beberapa kondisi, di antaranya adalah:

a. Ketika salah satu atau kedua belah pihak yang melakukan hubungan seksual telah melakukan perkawinan, yang mana akan dikenakan Pasal 284 KUHP yang mengatur tentang perzinahan (overspell). Pun, tindak pidana perzinahan merupakan suatu delik aduan, yang mana tindak pidana perzinahan hanya dapat diproses ketika suami atau istri dari salah satu pihak mengajukan penuntutan. Apabila tidak ada penuntutan, maka pelaku tidak dapat dipidana.

b. Ketika salah satu pihak melakukan hubungan seksual dengan paksaan, kekerasan dan ancaman kekerasan, maka akan dikenakan Pasal 285 KUHP yang mengatur perihal perkosaan.

c. Ketika seseorang memanfaatkan korban eksploitasi seksual dengan cara melakukan hubungan seksual, yang mana korban tersebut diduga atau diketahui masih anak-anak, maka dikenakan Pasal 76I jo. Pasal 88 UndangUndang No. 35 Tahun 2014 Tentang Perlindungan Anak yang mengatur perihal eksploitasi seksual terhadap anak.

Prostitusi sendiri pada dasarnya sama dengan melakukan hubungan seksual dengan seseorang atas dasar kemauan para pihak dan tanpa ada paksaan 
di dalamya. Namun yang membedakan dan yang membuat kegiatan prostitusi dapat dipidana adalah karena adanya pembayaran berupa uang sebagai imbalan atas apa telah dilakukan, dan kegiatan tersebut dimanfaatkan oleh pihak lain untuk mencari keuntungan dan dijadikan sebagai pencarian.

Prostitusi berasal dari Bahasa Latin yaitu pro-stituere atu pro-stauree yang berarti membiarkan diri berbuat zina, melakukan persundalan, pencabulan dan pergendakan. Sehingga pelacuran atau prostitusi bisa diartikan sebagai penjualan jasa seksual, seperti oral seks atau hubungan seks untuk uang. ${ }^{5}$

Prostitusi (pelacuran) secara umum diartikan sebagai praktik hubungan seksual sesaat oleh wanita yang dilakukan dengan siapa saja untuk imbalan berupa uang. Dalam praktik pelacuran terdapat 3 unsur utama yaitu pembayaran, promiskuitas, dan ketidak acuhan emosional. ${ }^{6}$

Prostitusi juga dikenal sebagai pelacuran. Sama halnya dengan Kartini Kartono yang menyebut prostitusi sebagai pelacuran. Dalam bukunya, ia memberi definisi pelacuran sebagai berikut: ${ }^{7}$

1. Pelacuranmerupakanperistiwapenjualandiridengangejalamemperjualbelikan badan, kehormatan, dan kepribadian seseorang untuk memuaskan nafsunafsu seks dengan imbalan pembayaran;

2. Prostitusi merupakan suatu bentuk penyimpangan seksual dimana seseorang mempunyai suatu dorongan untuk melakukan hubungan seksual sebagai bentuk pelampiasan nafsu yang tidak wajar dengan siapapun atau promiskuitas, ${ }^{8}$ disertai eksploitasi seks yang impersonal tanpa efeksi sifatnya;

3. Pelacuran adalah suatu perbuatan perempuan atau laki-laki dengan menyerahkan badan atau kehormatan untuk berhubungan seksual dengan mengharapkan imbalan atau upah.

\footnotetext{
5 Mutia Irna Jayanthi Lubis, 'Dampak Keberadaan Prostitusi Bagi Masyarakat Panjang', Skripsi (Universitas Lampung 2012).[12].

6 Bagong Suyanto, Masalah Sosial Anak (Kencana Prenada Media Group 2010).[159-160].

7 Kartini Kartono, Patologi Sosial (Rajawali Pers 1981).[177].

8 Promiskuitas adalah hubungan seksual antara sejumlah pria dengan wanita tanpa ada aturn yang mengikat; hubungan seks secara bebas dan ketidak acuhan emosi, melaksanakan hubungan seks tanpa emosi, tanpa perasaan cinta kasih atau afeksi dan dilakukan dengan pria manapun juga, dengan banyak laki-laki.
} 
Winda Hayu: Pertanggungjawaban Pidana Pengguna...

Kegiatan prostitusi mulanya dilakukan dengan kegiatan menjajakan diri di pinggir jalan untuk menarik para pembeli. Hal itu dilakukan baik oleh si pelaku sendiri maupun melalui mucikari. Namun saat ini, teknologi telah berkembang pesat sehingga kegiatan prostitusi semakin mudah untuk dilakukan. Negosiasi antara mucikari, pelaku, dan pembeli, bisa dilakukan kapan saja dan dimana saja melalui akun-akun media sosial.

Sedangkan untuk saat ini masih belum ada pengertian yang pasti dari kata prostitusi online, sebab dalam peraturan perundang-undangan di Indonesia, khususnya dalam UU ITE sama sekali tidak menyebutkan kata prostitusi online dalam rumusan-rumusan pasalnya. Kata online dalam hal ini merujuk pada kegiatan mucikari dalam membantu kegiatan prostitusi, dimana saat ini penawaran dan negosiasi antara mucikari dan pengguna jasa seringkali menggunakan media internet sebagai perantaranya. Sehingga dapat disimpulkan bahwa prostitusi online merupakan proses transaksi atau penjualan jasa seksual melalui internet atau sosial media untuk mendapatkan uang.

Di Indonesia, masih belum ada peraturan perundang-undangan yang mengatur secara rinci mengenai kegiatan prostitusi. Namun dalam KUHP, terdapat beberapa rumusan pasal yang secara tidak langsung mengatur tentang kegiatan prostitusi, di antaranya:

Pasal 296 KUHP yang berbunyi:

"Barangsiapa dengan sengaja menghubungkan atau memudahkan perbuatan cabul oleh orang lain dengan orang lain, dan menjadikannya sebagai pencaharian atau kebiasaan, diancam dengan pidana penjara paling lama satu tahun empat bulan atau denda paling banyak seribu rupiah".

Pasal 506 KUHP yang berbunyi:

"Barangsiapa menarik keuntungan dari perbuatan cabul seorang wanita dan menjadikan sebagai pencarian, diancam dengan kurungan paling lama satu tahun".

Melihat rumusan pasal-pasal tersebut di atas, aturan kita hanya terfokus pada kegiatan atau perbuatan seorang germo/mucikari saja. Larangan yang dituliskan hanya sekadar larangan untuk membantu perbuatan cabul orang lain kepada orang lain. Sedangkan kesalahan dari pihak lain yang membuat tindak 
pidana prostitusi ada menjadi tidak terjangkau oleh hukum, seperti pelaku dan pengguna jasanya.

Setelah banyak diundangkan peraturan-peraturan baru, terdapat beberapa aturan yang secara tidak langsung dapat digunakan sebagai payung hukum bagi tindak pidana di bidang prostitusi meski tidak dituangkan secara tersurat dalam rumusan pasal-pasalnya, di antaranya adalah:

a. Pasal 27 ayat (1) jo. Pasal 45 ayat (1) Undang-Undang Nomor 19 Tahun 2016 Tentang Perubahan Atas Undang-Undang Nomor 11 Tahun 2008 Tentang Informasi dan Transaksi Elektronik, dimana pasal tersebut mengatur larangan untuk mendistribusikan data yang bermuatan asusila. Pasal ini dapat menjerat para mucikari ataupun penyedia jasa ketika mereka melakukan promosi melalui media sosial dengan turut menyertakan foto-foto yang bermuatan asusila.

b. Pasal 4 ayat (2) Undang-Undang Nomor 44 Tahun 2008 Tentang Pornografi mengatur larangan untuk menyediakan jasa prostitusi, yang mana menyediakan jasa prostitusi merupakan tugas dari seorang mucikari dan penyedia jasa prostitusi.

c. Pasal 12 Undang-Undang No. 21 Tahun 2007 Tentang Pemberantasan Tindak Pidana Perdagangan Orang, yang mana mengatur larangan untuk memanfaatkan korban perdagangan orang dengan cara melakukan persetubuhan/prostitusi. Yang membedakan dari adanya ketentuan ini adalah status penyedia jasa yang bukan lagi menjadi pelaku melainkan menjadi korban.

d. Pasal 76I jo. Pasal 88 Undang-Undang No. 35 Tahun 2014 Tentang Perlindungan Anak megatur larangan untuk melakukan eksploitasi seksual terhadap anak, yang dapat diartikan sebagai segala pemanfaatan organ tubuh seksual dari anak untuk mendapatkan keuntungan. Salah satu cara untuk mendapat keuntungan tersebut adalah dengan cara melakukan persetubuhan/prostitusi. Disini, status anak adalah sebagai korban, bukan pelaku penyedia jasa prostitusi.

Selain itu, dalam tingkat daerah pun terdapat beberapa Peraturan Daerah yang memuat dan menjelaskan perihal larangan praktik prostitusi. Di antaranya akan dirangkum dalam tabel berikut di bawah ini: 


\begin{tabular}{l}
\hline PERATURAN DAERAH \\
\hline
\end{tabular}

Pasal 2

Siapapun dilarang mendirikan dan.atau mengusahakan serta menyediakan tempat untuk melakukan prostitusi.

Pasal 3

Selain larangan dalam Pasal 2 tersebut di atas, siapapun dilarang baik secara sendiri maupun kelompok, melakukan, menghub

ungkan, mengusahakan dan menyediakan orang untuk melakukan perbuatan prostitusi.

\section{Pasal 4}

Larangan dimaksud pada Pasal 3 berlaku juga bagi siapapun yang karena tingkah lakunya patut diduga dapat menimbulkan atau mengorbankan perbuatan prostitusi.

Pasal 7

Pelaku prostitusi baik laki-laki maupun perempuannya dikenakan sanksi sesuai dengan Pasal 9 Peraturan Daerah ini.

\section{Pasal 2}

(1) Setiap orang di Daerah baik sendiri-sendiri ataupun bersama-sama dilarang mendirikan dan/ atau mengusahakan atau menyediakan tempat dan/atau orang untuk melakukan pelacuran.

(2) Siapapun di Daerah dilarang baik secara sendiri ataupun bersama-sama untuk melakukan perbuatan pelacuran.

PERDA Kota Tangerang

Nomor 8 tahun 2005 Tentang

Pelanggaran Pelacuran

(3) Larangan sebagaimana dimaksud pada ayat (1) dan (2) Pasal ini berlaku juga bagi tempat-tempat hiburan, hotel, penginapan atau tempat-tempat lain di Daerah.

Pasal 3

Setiap orang dilarang membujuk atau memaksa orang lain baik dengan cara perkataan, isyarat, tanda, atau cara lain sehingga tertarik untuk melakukan pelacuran.

Pasal 42

(2) Setiap orang dilarang:

PERDA DKI Jakarta Nomor 8 Tahun 2007 Tentang Ketertiban Umum a. Menjadi pekerja seks komersial;

b. Menyuruh, memfasilitasi, membujuk, memaksa orang lain untuk menjadi penjaja seks komersial;

c. Memakai jasa penjaja seks komersial. 
Pasal 37

PERDA Kota Surabaya Nomor 2 Tahun 2014 Tentang Penyelenggaraan Ketertiban Umum dan Ketentraman Masyarakat

PERDA Kendari Nomor 9 Tahun 2017 Tentang Pencegahan dan Penanggulangan Perilaku Prostitusi
(2) Setiap orang dilarang:
a. menjadi pekerja seks komersial;
b. menyuruh, memfasilitasi, membujuk, memaksa orang lain untuk menjadi penjaja seks komersial;
c. memakai jasa penjaja seks komersial.

Pasal 4

Setiap orang dilarang menawarkan diri baik secara langsung dan/atau tidak langsung dengan menggunakan media informasi untuk melakukan prostitusi atau pelacuran.

Pasal 5

Setiap orang dilarang memanggil atau memesan pelacur baik secara langsung maupun tidak langsung dengan menggunakan media informasi dengan maksud untuk melakukan prostitusi atau pelacuran.

Pasal 6

Setiap orang baik secara sendiri maupun bersamasama dilarang untuk melakukan perbuatan pelacuran

Pasal 7

Setiap orang baik sendiri ataupun bersama-sama dilarang membujuk/merayu, mempengaruhi, memikat, mengajak, dan/atau memaksa orang lain dengan kata-kata, isyarat, tanda, dan/atau perbuatan lainnya yang dapat mengakibatkan perbuatan prostitusi atau pelacuran.

Merujuk pada isi tabel di atas, bisa dilihat jika aturan mengenai prostitusi lebih dirumuskan secara rinci di dalam peraturan di tingkat Daerah. Bahkan terdapat beberapa Peraturan Daerah yang tidak hanya melarang soal perbuatan mucikari/germonya saja, melainkan juga perbuatan para pihak yang terlibat dalam praktik prostitusi, seperti pelaku dan pengguna jasanya. Dengan ini, aturan di tingkat daerah sudah satu langkah lebih maju dari pada aturan hukum nasional. Di beberapa daerah, telah ada ketentuan yang dapat menjerat seluruh pelaku prostitusi termasuk mucikari, pengguna jasa, serta penyedia jasanya. Sedangkan dalam hukum nasional masih berlaku hanya untuk mucikari saja.

Sedangkan dalam RUU KUHP Tahun 2019 aturan mengenai prostitusi tetap tidak banyak berubah dari apa yang terdapat dalam KUHP yang berlaku saat ini. RUU KUHP tetap hanya mengatur perbuatan mucikari yang memudahkan 
perbuatan cabul orang lain dengan orang lain. Sedangkan perbuatan pihak lain yang terlibat dalam praktik prostitusi seperti penyedia jasa dan pengguna jasa masih belum ada aturan yang dapat menjerat mereka. Atura yang mengatur kegiatan prostitusi dirumuskan dalam Bagian Kelima tentang Perbuatan Cabul dan dalam Paragraf 2 tentang Memudahkan Percabulan dan Persetubuhan, yang terdapat dalam Pasal 426 hingga Pasal 429.

Meski begitu, dalam RUU KUHP, aturan mengenai prostitusi sedikit mengalami perluasan, dimana subyek hukumnya lebih diperinci dalam beberapa kelompok. Pasal 426 RUU KUHP mengatur bagi seorang yang memudahkan orang lain berbuat cabul atau bersetubuh dengan anak. Dalam ayat (2) dipersempit lagi dimana ketika perbuatan cabul atau persetubuhan dilakukan terhadap anak kandung, anak tiri, anak angkat, atau anak di bawah pengawasannya. Pasal 427 mengatur larangan seseorang yang memudahkan orang lain berbuat cabul atau persetubuhan yang dilakukan oleh pejabat pada bawahannya dan dokter, guru, pegawai, pengurus, atau petugas pada lembaga pemasyarakatan, lembaga negara tempat latihan karya, rumah pendidikan, rumah yatim dan/atau piatu, rumah sakit jiwa, atau panti sosial yang melakukan perbuatan cabul dengan orang yang dimasukkan ke lembaga, rumah, atau panti tersebut. Pasal 428 merupakan larangan ketika perbuatan pada Pasal 426 atau Pasal 427 dilakukan sebagai kebiasaan atau pekerjaan untuk mencari keuntungan. Dan dalam Pasal 429 mengatur larangan untuk menyerahkan anak kepada orang lain untuk melakukan perbuatan cabul dengan menjanjikan anak memperoleh pekerjaan.

\section{Aspek Kesalahan Pengguna Jasa Prostitusi Online}

Salah satu unsur seseorang dapat dikenakan pertanggungjawaban pidana adalah adanya unsur kesalahan, yang mana merupakan konsekuensi yuridis dari asas “Tiada Pidana Tanpa Kesalahan” (geen straf zonder schuld). Untuk menentukan adanya kesalahan, subyek hukum harus memenuhi beberapa unsur, diantaranya: (1) Adanya kemampuan bertanggungjawab pada si pembuat; (2) Hubungan batin antara si pembuat dan perbuatannya yang berupa kesengajaan (dolus) atau 
kealpaan (culpa); (3) Tidak adanya alasan penghapus kesalahan atau tidak adanya alasan pembenar dan pemaaf. ${ }^{9}$

Dalam melakukan perbuatannya, pengguna jasa menyadari bahwa ia telah berniat untuk melakukan tindak pidana prostitusi. Adanya negosiasi dengan mucikari perihal tempat dan harga dapat dikategorikan sebagai niat dan rencana. Dalam hal ini, pengguna jasa pasti mengetahui dan meniati perbuatannya untuk melakukan transaksi dengan dibantuolehmucikari. Penggunajasajuga mempunyai kemampuan bertanggungjawab, sebab dalam dirinya tidak ada alasan pembenar maupun pemaaf yang akan menghilangkan kemampuan bertanggungjawab. Namun dalam peraturan perundang-undangan di Indonesia, fokus larangan prostitusi hanya ditujukan kepada mucikari atau germo saja. Sedangkan pada pelaku prostitusi dan pengguna jasa masih belum dapat terjangkau oleh hukum nasional. Padahal, setiap pihak yang terdapat dalam praktik prostitusi melakukan perbuatan yang saling berhubungan, sebab apabila salah satu pihak tidak ada, maka kegiatan atau praktik prostitusi tidak akan pernah terjadi. Sehingga, saat ini pengguna jasa hanya bisa dipertanggungjawabkan melalui PERDA masingmasing daerah, karena dalam hukum nasional masih belum ada aturan yang dapat digunakan untuk menjerat para pengguna jasa prostitusi.

Sebab itu, pemidanaan terhadap mucikari saja tidak mencerminkan rasa keadilan, karena dalam perbuatan pelacuran terdapat subyek-subyek hukum yang berkaitan yakni mucikari, penyedia jasa, dan pengguna jasanya. ${ }^{10}$

\section{Pertanggungjawaban Pidana Pengguna Jasa Prostitusi Online}

Di Indonesia, terdapat asas legalitas hukum pidana yang diatur dalam Pasal 1 ayat (1) KUHP yang menyebutkan bahwa suatu perbuatan tidak dapat pidana, kecuali berdasarkan ketentuan perundang-undangan pidana yang telah ada. Asas ini merupakan salah satu asas yang digunakan dalam

\footnotetext{
9 Sudarto, Hukum dan Perkembangan Masyarakat (Sinar Baru 1983).[85].

10 Lucky Elza Aditya, ‘Urgensi Kriminalisasi Terhadap Pelacuran dalam Pembaharuan Hukum Pidana di Indonesia’ (2016) Jurnal Ilmiah.[5].
} 
Winda Hayu: Pertanggungjawaban Pidana Pengguna...

sistem pertanggungjawaban pidana. Selain itu, Indonesia juga menganut asas kesalahan, sehingga seseorang dapat dipertanggungjawabkan apabila terdapat kesalahan yang berupa tindak pidana yang dilakukan dan telah adanya aturan yang mengatur tindak pidana tersebut.

Pertanggungjawaban pidana mengandung makna bahwa setiap orang yang melakukan perbuatan tindak pidana yang sebagaimana dirumuskan dalam undang-undang, maka orang tersebut patut mempertanggungjawabkan perbuatan sesuai dengan kesalahannya. Dengan kata lain orang yang melakukan perbuatan tersebut akan mempertanggungjawabkan perbuatannya dengan pidana apabila ia mempunyai kesalahan. Dan seseorang dikatakan mempunyai kesalahan apabila terdapat pandangan normatif mengenai kesalahan yang telah dilakukan orang tersebut oleh masyarakat ketia ia melakukan perbuatan pidana. ${ }^{11}$

Dalam bukunya, Moeljatno menjelaskan bahwa untuk dapat dikatakan adanya kesalahan, maka seseorang harus memenuhi unsur-sunsur sebagai berikut: ${ }^{12}$

a. Melakukan perbuatan pidana (sifat melawan hukum);

b. Di atas umur tertentu yang mampu bertanggung jawab;

c. Mempunyai suatu bentuk kesalahan yang berupa kesengajaan atau kealpaan; dan

d. Tidak adanya alasan pemaaf.

Dalam perundang-undangan kita, aturan yang paling jelas dan mendekati perihal larangan prostitusi terdapat dalam Pasal 296 KUHP yang melarang setiap orang untuk dengan sengaja menyebabkan atau memudahkan perbuatan cabul orang lain dengan orang lain. Aturan tersebut hanya berlaku bagi mucikari saja, sedangkan untuk pelaku atau Pekerja Seks Komersial serta pengguna jasanya belum ada ketentuan yang dapat menjerat keduanya.

Namun dalam kegiatan prostitusi, yang melakukan perbuatan tidak hanya mucikari saja, tetapi ada beberapa pihak yang juga terlibat di antaranya adalah pengguna jasa prostitusi. Apabila suatu tindak pidana dilakukan oleh lebih dari satu orang, maka hal tersebut dinamakan penyertaan yang mana diatur dalam

\footnotetext{
11 Moeljatno, Aspek-Aspek Hukum Pidana (Rineka Cipta 2008).[41].

12 ibid.[177].
} 


\section{Pasal 55 KUHP.}

Pasal 55 ayat (1) ke-1 menyebutkan bahwa:

(1) Dipidana sebagai pelaku tindak pidana:

a. Mereka yang melakukan, yang menyuruh melakukan, dan yang turut serta melakukan perbuatan;

b. Mereka yang dengan memberi atau menjanjikan sesuatu, dengan menyalahgunakan kekuasaan atau martabat, dengan kekerasan, ancaman kekerasan, ancaman atau penyesatan, atau dengan memberi kesempatan, sarana atau keterangan, sengaja menganjurkan orang lain supaya melakukan perbuatan.

Merujuk pada Pasal tersebut di atas, Pengguna jasa dapat dikatakan sebagai pelaku yang turut melakukan sebab pengguna jasa juga turut serta dalam melakukan kegiatan prostitusi. Dikatakan turut serta, sebab pengguna jasa turut andil dalam melakukan negosiasi, baik melalui mucikari maupun dengan penyedia jasa secara langsung. Keduanya membuat suatu kesepakatan dengan tujuan yang sama yaitu mencari keuntungan. Dimana tugas dan peran mucikari adalah sebagai perantara antara penyedia jasa dan pengguna jasa untuk mempermudah dilakukannya hubungan seksual. Sedangkan pengguna jasa bersama dengan penyedia jasa sama-sama berperan sebagai pelaksana dalam melakukan hubungan seksual. Lebih lanjut, pengguna jasa juga berperan untuk membayar sejumlah uang sebagai imbalan karena dia dapat melakukan persetubuhan dengan seorang wanita, yang mana pembayaran tersebut merupakan suatu unsur yang harus terpenuhi dalam tindak pidana prostitusi.

Walaupun begitu, dalam Peraturan Daerah terdapat beberapa aturan yang mengatur secara rinci sanksi untuk para pengguna jasa prostitusi. Beberapa daerah yang telah mempunyai aturan tentang prostitusi di antaranya adalah Jakarta, Surabaya, Indramayu, Kendari, dan Tangerang.

Dalam Peraturan Daerah DKI Jakarta No. 8 Tahun 2007 Tentang Ketertiban Umum, dalam Pasal 42 ayat (2) jo. Pasal 61 menyebutkan setiap orang yang menggunakan jasa pekerja seks komersial dikenakan ancaman pidana kurungan paling singkat 20 (dua puluh) hari dan paling lama 90 (sembilan puluh) hari atau denda paling sedikit Rp. 500.000,- (lima ratus ribu rupiah) dan paling banyak Rp. 
Winda Hayu: Pertanggungjawaban Pidana Pengguna...

30.000.000,- (tiga puluh juta rupiah).

Dalam Peraturan Daerah Kota Surabaya Nomor 2 Tahun 2014 Tentang Penyelenggaraan Ketertiban Umum dan Ketentraman Masyarakat, dalam Pasal 37 ayat (2) jo. Pasal 46 menyebutkan setiap orang yang menggunakan jasa pekerja seks komersial dikenakan pidana kurungan palin lama 6 (enam) bulan atau denda paling banyak Rp. 50.000.000,- (lima puluh juta rupiah).

Dalam Peraturan Daerah Kota Kendari Nomor 9 Tahun 2017 Tentang Pencegahan dan Penanggulangan Perilaku Prostitusi, dalam Pasal 5 jo. Pasal 16 menyebutkan setiap orang yang memanggil atau memesan pelacur dengan maksud untuk melakukan kegiatan prostitusi diancam pidana kurungan paling lama 6 (enam) dan/atau denda paling tinggi Rp. 50.000.000,00 (lima puluh juta rupiah).

Apabila merujuk pada analisis di atas, maka dapat disimpulkan bahwa dalam aturan hukum Indonesia hanya terdapat aturan untuk menjerat mucikari/ germo saja. Sehingga pertanggungjawaban pengguna jasa hanya dapat dilakukan dengan pasal penyertaan atau dengan menggunakan Peraturan Daerah di masingmasing Daerah.

\section{Kesimpulan}

Hukum di Indonesia, masih belum ada peraturan yang mengatur secara rinci dan jelas untuk menjerat para pengguna jasa prostitusi online. Satu-satunya pihak yang dapat dikenakan hukuman adalah mucikari/germo saja, sehingga para pengguna jasa hanya dapat dipertanggungjawabkan dengan menggunakan Pasal 55 tentang penyertaan. Sebab prostitusi merupakan serangkaian kegiatan yang dilakukan oleh lebih dari satu pihak, dan semua pihak yang terlibat bersama-sama melakukan tindak prostitusi dengan tugas dan bagiannya masing-masing. Selain itu, para pengguna jasa juga dapat dipertanggungjawabkan melalui Peraturan Daerah masing-masing. Beberapa daerah yang telah mengatur ancaman pidana bagi pengguna jasa di antaranya adalah Peraturan Daerah DKI Jakarta, Surabaya, dan Kendari. 


\section{Daftar Bacaan}

\section{Buku}

Barda Nawawi Arief. Pornografi, Pornoaksi dan Cybersex-Cyberporn (Pustaka Magister 2011).

Kartini Kartono. Patologi Sosial (Rajawali Per 1981).

Moeljatno, Asas-Asas Hukum Pidana Edisi Revisi (Rineka Cipta 2008).

Sudarto. Hukum dan Perkembangan Masyarakat (Sinar Baru 1983).

Bagong Suyanto. Masalah Sosial Anak (Kencana Prenada Media Group 2010).

\section{Jurnal}

Lucky Erza Aditya,'Urgensi Kriminalisasi Terhadap PelacurandalamPembaharuan Hukum Pidana di Indonesia', (2016) Jurnal Ilmiah Universitas Brawijaya.

Khorrul Imam Syafrudin Kalo, dkk, 'Pertanggungjawaban Pelaku Tinda Pidana Prostitusi Online Ditinjau dari Undang-Undang Nomor 11 Tahun 2008 Tentang Informasi dan Transaksi Elektronik (Studi Putusan Nomor 267/ Pid.B/2015/PN. Pgp)' (2018) 6 USU Law Journal.

Subaidah Ratna Juita, dkk. 'Reformulasi Pertanggungjawaban Pidana pada Pelaku Prostitusi Online: Suatu Kajian Normatif' (2016) 8 Jurnal Dinamika Sosial Budaya.

\section{Skripsi}

Mutia Irna Jayanthi Lubis. 'Dampak Keberadaan Prostitusi Bagi Masyarakat Panjang', Skripsi (Universitas Lampung 2012)

Suprojo. 'Penegakan Hukum Pidana dalam Penanggulangan Pekerja Seks Komersial (PSK) di Kabupaten Demak', Skripsi (Universitas Negeri Semarang 2016) 
--Halaman ini sengaja dibiarkan kosong-- 